\title{
Performance of Mango (Mangifera indica L.) Monoembryonic and Polyembryonic Seedlings under Salt Stress Condition
}

\author{
J.S. Gora ${ }^{1 *}$, V.K. Singh ${ }^{2}$, D.K. Sarolia ${ }^{1}$, Kamlesh Kumar ${ }^{1}$, Rajkumar $^{3}$ and V. Bhati ${ }^{4}$ \\ ${ }^{1}$ ICAR-Central Institute for Arid Horticulture, Bikaner (Raj.), India \\ ${ }^{2}$ ICAR-CISH, Rehmankhera, Kakori, Lucknow (UP), India \\ ${ }^{3}$ ICAR-Central Soil Salinity Research Institute Karnal Haryana, India \\ ${ }^{4}$ Department of Horticulture, SKRAU, Bikaner Rajasthan, India \\ *Corresponding author
}

A B S T R A C T

\section{Keywords \\ Monoembryonic, Polyembryonic, Mango seedling, Bappakai, Abiotic stress, Salt. \\ Article Info \\ Accepted: \\ 29 May 2017 \\ Available Online: \\ 10 June 2017}

The experiment was laid out under net house condition on monoembryonic (Dashehari) and polyembryonic (Bappakai) mango variety seedling with 5 (five) treatments and having (one) replication under complete randomized design. The following morpho-physiological observations were recorded at three stages on $0^{\text {th }}$ day, $15^{\text {th }}$ day and $30^{\text {th }}$ day after the application of treatment to the tagged plants. Result revealed that inhibition of growth parameters with increasing intensity of salinity level and monoembryonic seedling showed more inhibition of growth as compared to polyembryonic seedling. Physiological parameters namely saturated weight, RWC, MSI and water potential drastically reduction in mono and polyembryonic seedlings with increasing salt concentration. The negatively highest water potential value and membrane get damaged was recorded in monoembryonic seedlings over polyembryonic cv. Bappakai. In polyembryonic seedlings symptoms of salinity stress were not observed in control, $15.8 \mathrm{~g} \mathrm{NaCl} / 10$ $\mathrm{kg}$ pot soil $\left(\mathrm{T}_{1}\right)$ and $31.6 \mathrm{~g} \mathrm{NaCl} / 10 \mathrm{~kg}$ pot soil $\left(\mathrm{T}_{2}\right)$.

\section{Introduction}

Mango occupies the largest chunk of fruit acreage, but it is well admitted that our present level of production is not sufficient enough. Successful mango cultivation is best with many intricate problems like biotic and abiotic stresses. Among these stresses, salinity is a serious problem in worldwide agriculture areas because it limits plant growth and productivity (Qin et al., 2010). In the mango, salinity affected plants produce symptoms like regrettably wilting, smaller fruit size, reduced photosynthesis and respiration, colour development of fruit, leaf scorching at tip, margins and curling. This problem can be mitigated through identification of suitable rootstocks as seedlings. Mango seeds can be classified into two groups, monoembryonic and polyembryonic, based on their mode of reproduction. Monoembryonic mango seed contain a single zygotic embryo, and hence only one seedling per seed, that is of probable hybrid origin. Polyembryonic mango seeds can contain one or more embryos, one of 
which usually, but not always zygotic. Adventitious embryos develop from the nucellus, a maternal tissue surrounding the embryo sac, and consequently the seedlings of polyembryonic mangoes are usually very similar to the maternal parent. Polyembryonic mangoes are heavy and consistent bearer. These are able to set fruit in the absence of a gametic embryo because of presence of nucellus embryos e.g. Bappakai, Simmonds, Cecil, Mulgoa, M13-1, James Saigon, Strawberry, Carabao, Pico, Olour and Cambodiana etc. Monoembronic mangoes bear good quality fruit, larger in size but are usually poor fruit setters and susceptible to many biotic and abiotic stresses as observed in monoembryonic varieties such as Dashaheri, Chausa, Langra and Amrapali etc (Singh, 1960; Sturrock, 1944; Campbell, 1961).

The poly embryonic mango has a great salt tolerance than mono embryonic population (Kadman et al., 1976). Poly embryonic mango mostly have poor fruit quality and have little commercial value but they have potential to be used as a root stock for saline/ alkaline soil or when irrigation water contains excess sodium or other soluble injurious ions for plants. The salt tolerant rootstocks M13-1 and Gomera-1 bear capacity to restrict the uptake and transport of $\mathrm{Cl}^{-}$and $\mathrm{Na}^{+}$ions from the rootstock to the above ground parts (Martinez et al., 1999; Jindal and Makhija, 1983; Dubey et al., 2007).

Salinization of agricultural land is increasing and in many areas salinity management is critical for the successful crop production. It appears to be sufficient genetic diversity exists within $M$. indica to enable the selection and development of saline tolerant rootstock, however quantitative data on the critical limits of soil and water salinity which mango trees will tolerate without optimal reduction in yield and fruit quality are needed. The prospect for future cultivation of salt tolerant/ resistant, high yielding genotypes of mango is very encouraging. Hence, the present investigation was undertaken to understand the performance of monoembryonic and polyembryonic mango seedlings under salt stress condition.

\section{Materials and Methods}

An experiment was carried out under net house condition at Plant Physiology Laboratory, Division of Crop Production, Central Institute for Subtropical Horticulture, Rehmankhera, Lucknow during May to August, 2014. The experiment was laid out under net house condition with 5 (five) treatments i.e., control $\left(\mathrm{T}_{\mathrm{o}}\right), 15.8 \mathrm{~g} \mathrm{NaCl} / 10$ $\mathrm{kg}$ pot soil $\left(\mathrm{T}_{1}\right), 31.6 \mathrm{~g} \mathrm{NaCl} / 10 \mathrm{~kg}$ pot soil $\left(\mathrm{T}_{2}\right), 37.487 \mathrm{~g} \mathrm{NaCl} / 10 \mathrm{~kg}$ pot soil $\left(\mathrm{T}_{3}\right)$ and $74.97 \mathrm{~g} \mathrm{NaCl} / 10 \mathrm{~kg}$ pot soil $\left(\mathrm{T}_{4}\right)$ on monoembryonic and polyembryonic (Bappakai) mango varieties in complete randomized design. Five plants were randomly selected from nursery of monoembryonic and polyembryonic each varieties for morphometric (plant height, number of leaves and root: shoot) and physiological (leaf water content, water potential and relative water content, membrane stability index) observations at three stages on $0^{\text {th }}, 15^{\text {th }}$ and $30^{\text {th }}$ days after the application of treatment to the tagged plants. Morphological characters namely plant height was measured in centimeter with a flexible measuring tape and numbers of leaves were counted every ten days and total all on per plant as well as ratio of root: shoot was calculated weight basis. Physiological parameters like leaf water status, leaf water potential $\left(\Psi_{\mathrm{W}}\right)$ was measured using WP4-T Dew Point Potential Meter (Wescor Inc., Logan, UT, USA), relative water content RWC $(\%)=[($ Fresh weight - Dry weight $) /$ (Turgid weight-Dry weight)] $x 100$ and membrane stability index MSI = $\quad\left(\begin{array}{lll}1 & -\end{array}\right.$ 
Electric conductivity at $40^{\circ} \mathrm{C} /$ Electric conductivity at $\left.40^{\circ} \mathrm{C}\right) \times 100$ calculated by using given formula.

\section{Results and Discussion}

\section{Morphological parameters}

The plant height, number of leaves and shoot: root both monoembryonic and polyembryonic seedlings showed inhibition of growth with increased intensity of salinity stress but monoembryonic seedlings showed more inhibition of shoot length as compared to polyembryonic seedlings. The maximum number of leaf drop in monoembryonic was recorded in the T-4 (42.16\%), however but all leaves were dried and attached to plant while least number of leaves dropped in control plant $(3.47 \%)$. In polyembryonic the maximum and minimum leaf drop was in T-4 $(73.3 \%)$ and $\mathrm{T}-0(1.14 \%)$, respectively.

Stress symptoms on the leaves of monoembryonic seedlings under $\mathrm{T}-0, \mathrm{~T}-1, \mathrm{~T}-$ 2, T-3, T-4 as number of leaves were observed to have 0,35 (19.12\%), 41 (28.87\%), $87 \quad(53.04 \%), \quad 68 \quad(100 \%)$ respectively, while in polyembryonic mango cv. Bappakai T-0, T-1, T-2, T-3, T-4 were recorded $0,0,3(7.31 \%), 20(20.20 \%), 30$ $(100 \%)$ respectively.

It is evident from the result that $\mathrm{NaCl}$ treatments caused inhibition in plant growth due to decrease in proliferation ratio, fresh weight, shoot length, number of leaves (Zidan et al., 1990, Tonon et al., 2004). Since plant growth is result of massive and irreversible expansion of young cells produced by ongoing meristematic divisions, salinization can inhibit both cell division and cell expansion in growing tissue of roots stem and leaves thereby affecting shoot growth (Aazami et al., 2010, Giner, et. al 2011). Plant height, number of leaves per plant and fresh weight of root and shoot exhibited significant positive association with increasing salinity level due to non-absorption of minerals and water (Asrey Ram and Shukla, 2003)

\section{Physiological parameters}

Observation of saturated weight was recorded in monoembryonic and polyembryonic seedlings at 0 to 6 hours. Saturated weight was obtained first in monoembryonic as compared to polyembryonic. The saturation point of leaves under both monoembryonic and polyembryonic were obtained first in control (T-0) and thereafter in T-1, T-2, T-3 and T-4. The reduction of RWC in both monoembryonic and polyembryonic seedlings with increased intensity of salt salinity was evident in all the treatments under study. The highest relative water content was recorded in control seedling leaves (T-0) of both monoembryonic $(98.80 \%), \quad$ and polyembryonic $(96.40 \%)$ types.

Relative water content of monoembryonic leaves was drastically reduced from $98.80 \%$ in control plants to $71.0 \%$ in the stressed plant (T-4) whereas in polyembryonic cv. Bappakai it was reduced from $96.4 \%$ in control plants to $94.40 \%$ in stressed plants (T4). Relative water content in the leaves of plants grown under salinity stress decreased significantly in both monoembryonic and polyembryonic seedlings compared to those of control (T-0).

LWC too followed similar trends as RWC. Similar finding were reported by Navarro et al., 2003, Suarez and Medina, 2008 that significant reduction of RWC and LWC in leaves of plants treated with 400 and 600 $\mathrm{mmol} / \mathrm{l}$ indicated that salinity also resulted in dehydration at cellular level and dehydration symptoms were greater in $\mathrm{NaCl}$ concentration treatment because of the increasing cellular water loss. One of the early symptoms of 
salinity stress in plant tissue is the decrease (RWC). This reduction of RWC is stressed plant may be associated with a decrease in plant vigor, Chlorophyll degradation.

Table.1 Observation recorded after 30 day of treatment

\begin{tabular}{|c|c|c|}
\hline Treatments & Monoembryonic seedling & $\begin{array}{l}\text { Polyembryonic Mango cv. } \\
\text { Bappakai }\end{array}$ \\
\hline $\mathrm{T}-0$ & No symptoms & No symptoms \\
\hline $\mathrm{T}-1$ & $\begin{array}{l}\text { Leaf scorched from tips and margin } \\
\text { were started chlorosis of leaves }\end{array}$ & No symptoms \\
\hline $\mathrm{T}-2$ & $\begin{array}{l}\text { Small necrosis and yellowing of leaves } \\
\text { spot appeared, Leaf margins and tips } \\
\text { started burnt and look liked brown } \\
\text { Drying of leaves were starting fall down }\end{array}$ & Tips of leaves started burning \\
\hline $\mathrm{T}-3$ & $\begin{array}{l}\text { Enlarge of necrotic appeared spot on } \\
\text { leaves, leaf yellowing, curling and } \\
\text { burning leaves were drying and fall } \\
\text { down plant died }\end{array}$ & $\begin{array}{l}\text { Yellowing of leaves } \\
\text { Tips and margin shown burnt }\end{array}$ \\
\hline $\mathrm{T}-4$ & $\begin{array}{l}\text { Large necrotic spot, burning of leaf tips } \\
\text { and margins appeared plant were } \\
\text { weaken, drying and fall down of leaves }\end{array}$ & $\begin{array}{l}\text { large necrotic and Burning } \\
\text { spot appeared on leaves } \\
\text { margin and tips } \\
\text { drying of leaves and fall down }\end{array}$ \\
\hline
\end{tabular}

Table.2 Effect of salinity stress on morphological characters of monoembryonic seedlings and Polyembryonic Mango cv. Bappakai

\begin{tabular}{|c|c|c|c|c|c|c|c|c|c|}
\hline \multirow[t]{2}{*}{ Varieties } & \multirow[t]{2}{*}{$\begin{array}{l}\text { Treatme } \\
\text { nts }\end{array}$} & \multicolumn{3}{|c|}{$\begin{array}{l}\text { Plant height } \\
\text { (cm) }\end{array}$} & \multicolumn{3}{|c|}{ No. of leaves } & \multicolumn{2}{|c|}{$\begin{array}{l}\text { Root : Shoot } \\
\text { (weight basis) }\end{array}$} \\
\hline & & 0 & 15 & 30 & 0 & 15 & 30 & Fresh & Dry \\
\hline \multirow{5}{*}{$\begin{array}{l}\text { Monoembr } \\
\text { yonic } \\
\text { seedlings }\end{array}$} & $\mathrm{T}-0$ & 159 & 162 & 164 & 144 & 141 & 139 & 5.43 & 8.28 \\
\hline & $\mathrm{T}-1$ & 117.0 & 118 & 119 & 183 & 175 & 160 & 5.59 & 6.83 \\
\hline & T-2 & 137 & 138 & 138 & 142 & 130 & 118 & 5.82 & 6.66 \\
\hline & T-3 & 147 & 147 & 147 & 164 & 152 & 140 & 2.60 & 6.34 \\
\hline & $\mathrm{T}-4$ & 81 & 81 & 81 & 68 & 58 & 46 & 2.60 & 4.75 \\
\hline \multicolumn{2}{|l|}{$\overline{\text { SEm+ }}$} & 2.84 & 2.77 & 2.76 & 3.23 & 3.01 & 2.75 & 0.09 & 0.14 \\
\hline \multicolumn{2}{|l|}{ CD at $5 \%$} & 8.95 & 8.73 & 8.72 & 10.18 & 9.49 & 8.69 & 0.31 & 0.44 \\
\hline \multirow{5}{*}{$\begin{array}{l}\text { Polyembry } \\
\text { onic mango } \\
\text { cv. } \\
\text { Bappakai }\end{array}$} & T-0 & 97 & 101 & 103 & 89 & 87 & 85 & 4.55 & 5.17 \\
\hline & T-1 & 87 & 88 & 89 & 42 & 38 & 33 & 2.14 & 4.40 \\
\hline & T-2 & 95 & 95 & 95 & 41 & 37 & 31 & 3.29 & 4.24 \\
\hline & T-3 & 113 & 113 & 113 & 99 & 93 & 84 & 4.27 & 3.95 \\
\hline & T-4 & 66 & 66 & 66 & 30 & 24 & 08 & 2.21 & 3.87 \\
\hline \multicolumn{2}{|l|}{ SEm+ } & 1.36 & 1.25 & 1.26 & 0.90 & 0.71 & 0.62 & 0.04 & 0.20 \\
\hline \multicolumn{2}{|l|}{ CD at $1 \%$} & 4.29 & 3.95 & 3.98 & 2.84 & 2.22 & 1.97 & 0.13 & 0.63 \\
\hline
\end{tabular}


Table.3 Effect of salinity stress on physiological characters of mono and Polyembryonic mango seedlings

\begin{tabular}{|c|c|c|c|c|c|c|c|c|c|}
\hline \multirow[t]{2}{*}{ Varieties } & \multirow[t]{2}{*}{ Treatments } & \multicolumn{5}{|c|}{ Leaf water status } & \multirow[b]{2}{*}{ RWC } & \multirow[b]{2}{*}{ WP } & \multirow[b]{2}{*}{ MSI } \\
\hline & & 0 hrs. & 2 hrs. & $4 \mathrm{hrs}$. & $6 \mathrm{hrs}$ & Dw (g) & & & \\
\hline \multirow{5}{*}{$\begin{array}{l}\text { Monoemb } \\
\text { ryonic } \\
\text { seedlings }\end{array}$} & $\mathrm{T}-0$ & 2.17 & 2.18 & 2.19 & 2.20 & 0.84 & 98.80 & -6.15 & 37.0 \\
\hline & $\mathrm{T}-1$ & 1.66 & 1.69 & 1.72 & 1.72 & 0.67 & 94.50 & -6.56 & 30.0 \\
\hline & $\mathrm{T}-2$ & 2.17 & 2.23 & 1.26 & 2.26 & 0.91 & 93.00 & -8.20 & 28.00 \\
\hline & $\mathrm{T}-3$ & 1.00 & 1.09 & 1.20 & 1.20 & 0.50 & 92.10 & -10.68 & 16.00 \\
\hline & $\mathrm{T}-4$ & 1.67 & 1.68 & 1.75 & 1.76 & 0.68 & 71.70 & -10.91 & 14.00 \\
\hline \multicolumn{2}{|l|}{ SEm \pm} & 0.03 & 0.04 & 0.03 & 0.02 & 0.02 & 1.96 & 0.20 & 0.52 \\
\hline \multicolumn{2}{|l|}{ CD at $5 \%$} & 0.12 & 0.12 & 0.10 & 0.09 & 0.05 & 6.20 & 0.63 & 1.65 \\
\hline \multirow{5}{*}{$\begin{array}{l}\text { Polyembr } \\
\text { yonic } \\
\text { mango cv. } \\
\text { Bappakai }\end{array}$} & $\mathrm{T}-0$ & 1.97 & 1.97 & 2.01 & 2.02 & 0.78 & 96.40 & -6.64 & 50.0 \\
\hline & $\mathrm{T}-1$ & 2.33 & 2.34 & 2.37 & 2.38 & 1.07 & 96.19 & -6.70 & 33.0 \\
\hline & $\mathrm{T}-2$ & 1.74 & 1.76 & 1.78 & 1.79 & 0.69 & 95.80 & -6.74 & 28.60 \\
\hline & $\mathrm{T}-3$ & 2.06 & 2.09 & 2.12 & 2.12 & 0.77 & 95.50 & -7.08 & 16.66 \\
\hline & $\mathrm{T}-4$ & 1.74 & 1.80 & 1.79 & 1.79 & 0.74 & 94.40 & -7.54 & 14.28 \\
\hline \multicolumn{2}{|l|}{ SEm \pm} & 0.03 & 0.02 & 0.03 & 0.04 & 0.01 & 1.42 & 0.10 & 0.43 \\
\hline \multicolumn{2}{|l|}{ CD at $5 \%$} & 0.09 & 0.06 & 0.10 & 0.12 & 0.04 & 4.48 & 0.33 & 1.37 \\
\hline
\end{tabular}

There was a marked and progressive decline in leaf water potential $\left(\varphi_{\mathrm{w}}\right)(-\mathrm{MPa})$ in leaves of monoembryonic and polyembryonic seedlings with increasing salinity stress (Table 3). The negatively highest and lowest water potential in monoembryonic was noted in T-4 (-10.91) and T-0 (-6.15) respectively whereas in polyembryonic seedlings water potential of $\mathrm{T}-0, \mathrm{~T}-1, \mathrm{~T}-2, \mathrm{~T}-3, \mathrm{~T}-4$ were recorded at $-6.64,-6.70,-6.74,-7.08,-7.54$ ($\mathrm{MPa}$ ) respectively.

The similar findings were recorded by Rahman et al., (2002), Meloni et al., (2004) in citrus lowering of osmotic potential results due to an in intracellular solutes which is an adopted mechanism of plants to external stress. It allows the maintenance of turgor under salinity stress as a result of which plant becomes able to maintain the vital process and survive. Qin et al., (2010) also reported that progressive decline leaf water potential in leaves of seedlings with increasing salinity. The decrement of water potential were $11.8 \%$, $24.9 \%$ and $37 \%$ at 200, 400, $600 \mathrm{mmol} / 1$, respectively when compared with the control. MSI decreased under salt stress in all the monoembryonic and polyembryonic seedlings for all $\mathrm{NaCl}$ treatments. Maximum MSI was noted in control seedling (T-0), monoembryonic at $(37.0 \%)$ and polyembryonic at $(50.0 \%)$ while the lowest reduction were at T-4 viz. $14.0 \%$ and $14.28 \%$ for monoembryonic and polyembryonic treatments, respectively.

Since, membranes get damaged with increase in salinity level, so MSI can be considered as a very significant tool for evaluating salt tolerance potential in mango cultivars. The present study was recorded by Shahid et al., 2012 that membrane stability index (MSI) reported to decrease under salt stress in Pisum sativum at all $\mathrm{NaCl}$ treatments but maximum reduction was noted less than $75 \mathrm{mM} \mathrm{NaCl}$. Under salinity stress MSI of Sehar-06 and Lu -26 were negatively influence than the control condition. Thus, growth parameters with increasing intensity of salinity level showed more inhibition of growth such symptoms 
more pronounced in monoembryonic as compared to polyembryonic seedling. In polyembryonic seedlings symptoms of salinity stress were not observed in control, $15.8 \mathrm{~g} \mathrm{NaCl} / 10 \mathrm{~kg}$ pot soil $\left(\mathrm{T}_{1}\right)$ and $31.6 \mathrm{~g}$ $\mathrm{NaCl} / 10 \mathrm{~kg}$ pot soil $\left(\mathrm{T}_{2}\right)$ and vice versa negatively highest water potential value and membrane get damaged was recorded in monoembryonic seedlings over polyembryonic cv. Bappakai.

\section{References}

A. Kadman, S. Gazit, G. Ziv., 1976 Selection of mango rootstock for adverse water and soil conditions in arid areas. Acta Hort, 57 (1976), pp. 81-88

Aazami, M. A. Torabi, M. and Shekari, F. 2010. Response of some tomato cultivars to sodium chloride stress under in vitro culture condition. Aust. J. Agri. Res. 5: 2589-2592.

Asrey, R. and Shukla, H. S. 2003. Salt stress and correlation studies in pomegranate (Punica granatum L.) Ind. J. Horti. 60(4): 330-334.

Campbell, C.W. 1961. Comparision of yield of polyembryonic and monoembryonic mangos. Florida Agricultural Experiment Stations Journal Series No. 1347. Pp 363-365

Dubey, A.K, Singh A.K. and Srivastav, M. 2007 SALT STRESS STUDIES IN MANGO- A REVIEW. Agric. Rev, 28(1):75-78, 2007

Giner, M. A. Legaz, F. Primo-Millo, E. and Forner, J. 2011. Nutritional responses of citrus rootstocks to salinity; performance of new hybrids. Plant nutr. 34: 1437-1452.

Jindal, P.C. and Makhija, M. 1983. Progressive Horticulture 15(3): 226-228.

Martinez. 1999. Irrigation under Conditions of Water Scarcity Vol. IG 17th International Congress on Irrigation and Drainage, Granada, Spain. Published In Commission on Irrigation and Drainage. pp 61-71.

Meloni, D. A. Oliva, M.A. Martinez, C. A. 2003. Photosynthesis and activity of superoxide dismutase peroxidase and glutathione reductase in cotton under salt stress. Environ Exp Bot 49: 69-76

Qin, J. Dong, W.Y. He, K.N. Yu, Y. Tan, G.D. Han, L. Dong, M. Zhang, Y.Y.

Rahman, M. S. H. Miyake and Y. Takeoka. 2002. Effects of exogenous glycinebetaine on growth and ultrastructure of salt-stressed rice seedlings (Oryza sativa L.). Plant Prod. Sci., 5:33-44.

Shahid, M. A. Balal, R. M. Pervez, M. A. Abbas, T. Ashfaq, M. Ghazanfar, U. Afzal, M. Rashid, A. Garcia-Sanchez, F. and Mattson. N. S. 2012. Differential response of pea (Pisum sativum L.) genotypes to salt stress in relation to the growth, physiological attributes antioxidant activity and organic solutes. Aust. J. Crop Sciences 6(5):828-838.

Singh, L.B. 1960. The mango. Interscience Publishers, Inc., New York: 22-25.

Sturrock, D. 1944. Notes on the mango. Stuart Dally News, Inc., Stuart, Florida: 105-108.

Tonon, G. C. Kevers, O. Faivre-Rampant, M. Graziani and T. Gaspar. 2004. Effect of $\mathrm{NaCl}$ and mannitol iso-osmotic stresses on proline and free polyamine levels in embryogenic Fraxinus angustifolia callus. J. Plant Physiol. 161:701-8.

Zhang, Y.Y, Li, A.Z. and Wang, Z.L. 2010. NaCl salinity-induced changes in water status, ion contents and photosynthetic properties of Shepherdia argentea (Pursh) Nutt. Seedlings. Plant soil environ. 56:325-332.

Zidan, I. Azaizeh, H. and Neumann, P. M. 1990. Does salinity reduce growth in maize root epidermal cells by inhibiting their capacity for cell wall acidification? Plant physiol. 93: $7-11$.

\section{How to cite this article:}

Gora, J.S., V.K. Singh, D.K. Sarolia, Kamlesh Kumar, Rajkumar and Bhati, V. 2017. Performance of Mango (Mangifera indica L.) Monoembryonic and Polyembryonic Seedlings under Salt Stress Condition. Int.J.Curr.Microbiol.App.Sci. 6(6): 3051-3056. doi: https://doi.org/10.20546/ijcmas.2017.606.363 